\title{
The goat farming management for arid and desert zones: a technical approach to produce high quality milk during all the year
}

\author{
El manejo en la crianza de cabra en zonas áridas y desérticas; \\ un enfoque técnico para producir leche de alta calidad durante todo el año
}

Juan Scopinich-Cisternas ${ }^{1}$, Erwin Strahsburger ${ }^{1 *}$

\begin{abstract}
The maximum milk yield of dairy goats depends of its genetics and managements procedures. If dairy goats come from Template or Mediterranean weather and are introduced in a similar environment, their managements seem not so relevant, being highly productive even including the grazing goats. Meanwhile, if these dairy goats are introduced in a desert and arid zones, probably they will be not well adapted to this new environment and their milk production will be more dependents of their management procedures. Therefore, considering a desert zones as a general stress factor in goat farming, in this review we analyzed and discuss diverse managements procedures related with goat milk production, like control of mating season, prolificacy, length of lactation period and maturity of doe at time of first lactation, to suggest a general managements procedures of goat farming to produce goat milk with economic interest. Following the present managements proposal, would be possible to produce high quality goat milk during all the year and if goat type is well adapted to arid or desert zones, the goat rancher will obtain economic earns from this activity.

Keywords: Saanen, Creole, Casein, Lactation, Mating, Photoperiod.
\end{abstract}

\section{RESUMEN}

La máxima producción de leche en cabras lecheras depende de su genética y de los procedimientos de manejo. Si la cabra lechera proviene de un clima templado o mediterráneo y son introducidas en un ambiente similar, su manejo parece ser no tan relevante, siendo altamente productivas incluso las cabras de pastoreo. Mientras que si estas cabras lecheras son incorporadas en zonas áridas o desérticas, probablemente ellas no se adaptarán bien a este nuevo ambiente, y su producción lechera sería más dependiente de sus procedimientos de manejo. Por lo tanto, considerando una zona desértica como un factor de estrés general en la ganadería caprina, en esta revisión analizamos y discutimos diversos procedimientos de manejo relacionados con la producción de leche de cabra como el control del periodo de apareamiento, la prolificidad, la duración del período de lactancia y la madurez de la hembra al momento de la primera lactancia, para sugerir un procedimiento de manejo general en la ganadería caprina para producir leche de cabra con un interés económico. Si se siguen estas propuestas de manejo, sería posible producir leche de cabra de alta calidad durante todo el año, y si el tipo de cabra está bien adaptado a las zonas áridas y desérticas, el ganadero caprino obtendrá ganancias económicas con esta actividad.

Palabras Claves: Saanen, Criolla, Caseína; Lactancia, Cruza, Fotoperiodo.

\section{Introduction}

Goat farming is a family activity with a significant social role in arid and desert zones. Its aim is produce goat milk with high content of protein and fats, through the selection of best herd animals for crossbreeding. A high efficiency in energy conversion is expected in these selected animals, transforming efficiently food in milk. This take the opportunity of obtain all nutrient from foods sometimes scare or which are not so enriched in nutrients, when are produced in desert and arid zones. Therefore, goat farming with economic interest has two mains components; the goat intrinsic factors which is genetically defined and the extrinsic factors which did not belong to the animal, instead is related with its managements and can be adjusted according to the environmental

\footnotetext{
1 Molecular Biotechnology Laboratory, Faculty of Renewable Natural Resources, Universidad Arturo Prat, Iquique, Chile.

* Corresponding author: estrahsb@unap.cl
}

Fecha de Recepción: 5 de Junio, 2017.

Fecha de Aceptación: 31 de Marzo, 2018. 
conditions and the own goat traits. Among these extrinsic factors we can mention it; age of calving, lactancy state, prolificacy, dry period and corporal condition (Salvador y Martínez, 2007). The impact of each extrinsic factor on milk production has to be studied independently and statistically to avoid misinterpretation with the natural variance of each goat genotype. From this statistics analysis is possible to establish management programs driven to improve goat milk yield in goat farming (Bedoya et al., 2012). Considering the social relevance of goat milk production in families located in arid and desert zones, is necessary to promote local studies aimed to determine the effect of each extrinsic factors on goat milk yield and its adjustment to sustain this rancher activity with a commercial purpose.

\section{Extrinsic factors that affect lactation}

Lactation is the period that the doe naturally feed its baby with its milk. In that period their production is related with the ecology and physiological response of the animal against all those factors that could cause distress. In productive managements, usually the baby is separated from its mother, although still is fed with a portion of the total volume of her extracted milk. On that productive period the wellness of the dairy goat has to be carefully supervised to avoid infections that produce mastitis among other diseases, as well as, a continuously verification of the quality of their food and freshwater administrated to the productive herd. In this review these cares including the sanitary conditions of the goat farm and the milk extraction system will be considered under acceptable standard conditions to perform milk production. Therefore, our analysis and discussion will be focused mainly on the effects on milk production due to: the length of lactation period, prolificacy, dry period, morphological traits of the animal and photoperiods. All these factors have to be controlled and measured to establish an appropriate management of goat milk production in arid and desert zones, besides of the minimal standards condition mentioned above.

\section{Lactation periods}

In goat farming the lactation period could be divide in three stages; an initial period of milk production, a stage of maximum volume of milk produced that not necessarily correspond to the middle of the total length of the period and a final stage marked by a gradually daily decay in milk production until reach the end. Then, the lactation curve could be expressed in terms of lactation days and kilograms of milk produced during the total period. After the end of lactation curve, the doe usually rest for a period of time before to be crossed again to get pregnant and give a birth to begin another lactation period. In this productive management the doe age is defined according to the numbers of complete lactation periods instead of their biological age. The first calving is usually associated with low milk production because their body is still in development and possesses juvenile udders that still not reach a maximum productive rate (Goetsch et al., 2011). In general, between the third and fourth lactation periods a maximum milk production is reached (Cofre, 2001). Then, during fifth and sixth lactation period the milk production begin to decay as the natural results of physiological weathering (Goetsch et al., 2011). Therefore, in productive terms the lactation period will be productive according to the total volume of milk produced, and not by the length of the periods expressed as totals of days. That means that a good productive goat will produce more milk in a certain period of time in comparison with others not productive goats that will produce less total volume of milk even considering a longer lactation period. Thus, the analysis of lactation period contributes to establish the main milk productive period of each goat avoiding its anticipated discarding and clarifying the right moment to refresh the herd.

The lactation period and milk production are different between diverse goat breeds (Table 1). In double purpose breeds (meat and milk) Red Sokoto, Sahel y West African Dwarf, a progressive increase in milk production occurs between 1st and 3rd lactation (Zahradeen et al., 2009), meanwhile, in Saanen and Alpine breeds occurs at 4th lactation period (Mioc et al., 2008). In Murciano-Granadinas goats, the maximum milk yield observed at first, second and third lactation period was the half (around $1.78 \mathrm{Kg} \cdot \mathrm{d}^{-1}$ ) of those produced by French-Alpine, American-Alpine, Saanen half-breed, Toggenburg and British-Alpine goat breed (around 3.1 Kg.d ${ }^{-1}$ ) (Leon et al., 2007). Hence, from lactation curve the production of 
Table 1. Differences in milk yield and milk compositions between diverse goat breeds.

\begin{tabular}{|c|c|c|c|c|c|}
\hline \multirow{2}{*}{ Breed } & \multicolumn{4}{|c|}{ Factors } & \multirow{2}{*}{ References } \\
\hline & Lactation (kg/goat/day.) & Lactation (days) & Lipids (\%) & Protein $(\%)$ & \\
\hline \multirow{5}{*}{ Saanen } & 3.35 & 228 & 3.56 & - & Bidot, 2013 \\
\hline & 2.78 & 278 & 5.59 & 3.46 & Salvador and Martínez, 2007 \\
\hline & 2.75 & 269 & 3.20 & 2.70 & Cofré 2001 \\
\hline & 1.56 & - & 3.50 & 5.44 & Noguera, et al., 2011 \\
\hline & 1.27 & - & - & 3.43 & Frau, 2010 \\
\hline \multirow{2}{*}{ Toggenburg } & 3.23 & 235 & 3.33 & - & Bidot, 2013 \\
\hline & 2.73 & 257 & 3.90 & 2.80 & Cofré, 2001 \\
\hline \multirow{3}{*}{ Alpina } & 2.76 & 273 & 3.58 & 31.4 & Salvador and Martínez, 2007 \\
\hline & 2.38 & 256 & 3.60 & 2.90 & Cofré, 2001 \\
\hline & 0.87 & - & 4.27 & 2.86 & Noguera, et al., 2011 \\
\hline Nubian & 2.85 & 215 & 4.57 & - & Bidot, 2013 \\
\hline Anglo Nubian & 0.96 & - & 6.06 & 3.43 & Frau, 2010 \\
\hline
\end{tabular}

maximum volume of milk can be deduced. That depends of genetic and external factors like calving season, the length of lactation period and the total volume of milk produced. If is known the genetics factors, the lactation curve can give the potential of milk production shortly after the delivery, being an important tool to be included in goat farming strategies in arid and desert zones (Espinosa et al., 2016). For example, a study about lactation curve in several flocks of Beetal goat breed in Pakistan showed a sharped curve of lactation. That means that total volume of milk produced at initial, pick and the end of lactation period was similar. Besides, they showed that type of birth and age of the doe affected the lactation curve, but not the parity and the sex of the kids. In fact, they proposed that from lactation curve is possible to evaluate the performance of each doe, take decision about the renewal of the herd or make changes in the management procedures to improve milk production (Waheed and Khan, 2013).

The establishment of length of lactation period is frequently done according to the physiological and histological characteristic of the mammary gland. However, local goat ranchers lack of research instruments to perform histological analysis, being necessary others parameters like fat content to be used or demanded by them. In a study with Murciano-Granadinas goats under sucking and milking machine treatments, they showed that in both cases the fat content decay meanwhile milk production was increasing. In fact, the date of lowest fat content was registered one day before the maximum milk production was observed. After that period, the fat content remains stable and milk production start to decay (Peris, 1997). In this sense, the lowest fat content was an indirect measurement of the start of decaying of milk production, and can be used as an indirect marker in lactation curve.

The length of lactation period and the total volume of milk produce will change according to the goat breed (Table 2). Chilean creole goat reaches a maximum production of $103.7 \mathrm{Kg}$ per lactation during the second lactation period (Table 2). However, any studies has defined if others creole goat across Chile, which possess different environments though all this thin land, has the same genetic background and same traits in goat milk production. Therefore, we suggest that more studies are needed to determine the milk productivity of Chilean creole goats present in arid and desert zones and if some parameters like fat contents are also related with the lactation curve.

\section{Prolificacy}

A recurrent belief among farmers is that multiple birth goats usually are more productive than single birth. However, in literature that is not so conclusive. In Murciano-Granadinas breeds the prolificacy does not affect milk yield (Peris et al., 1997), but in Payoya breed, animals with two offspring produced a total of 
Table 2. Milk yield and length of lactation period in diverse goat breed.

\begin{tabular}{|c|c|c|c|c|c|}
\hline \multirow{2}{*}{ Breed } & \multicolumn{4}{|c|}{ Factors } & \multirow[t]{2}{*}{ References } \\
\hline & $\mathrm{N}^{\circ}$ of Calving & $\mathrm{Kg} / \mathrm{Lactation}$ & Length Lactation/days & $\mathrm{n}$ & \\
\hline \multirow{4}{*}{ Maltese } & 1 & 86.6 & 177.8 & 324 & \multirow{4}{*}{ Carnicella et al., (2008) } \\
\hline & 2 & 100.3 & 179.4 & 280 & \\
\hline & 3 & 111.3 & 180.2 & 180 & \\
\hline & 4 & 118.3 & 185.1 & 205 & \\
\hline \multirow{4}{*}{ Chilean creole } & 1 & - & - & - & \multirow{4}{*}{ Pérez et al., (1993) } \\
\hline & 2 & 103.7 & 196 & 12 & \\
\hline & 3 & 97.2 & 196 & 19 & \\
\hline & 4 & 70.5 & 196 & 10 & \\
\hline \multirow{4}{*}{ Majorera } & 1 & 267.7 & 242.1 & 210 & \multirow{4}{*}{ Fernández y Mernies (2016) } \\
\hline & 2 & 447.0 & 242.1 & 210 & \\
\hline & 3 & 462.6 & 242.1 & 210 & \\
\hline & 4 & 463.3 & 242.1 & 210 & \\
\hline
\end{tabular}

129.7 liters of milk, meanwhile, goats with one offspring produced a total of 96.3 liters of milk (Delgado-Pertiñez et al., 2009). Similar results were observed in Mexican creole, Nubian and Celtiberic breed, where goats with twins produced $1.036 \mathrm{Kg}$ of milk.d ${ }^{-1}$ in comparison with 0.742 $\mathrm{Kg}$ of milk $\mathrm{d}^{-1}$ produced by goats with only one offspring (Sanchez de la Rosa et al., 2006). These results apparently suggest that goats with multiple births are more productive than single birth, because a higher volume of milk is produced. However, in a study with Greece goats (Capra prisca), the milk quality (protein, lactose and fats content) was lower in goat with twins than in goat with single kid, explaining the smaller size of twins (Zygoyiannis, 1994). That suggests about prolificacy, that more milk volume not necessary involve more volume of high quality milk.

There are two mains theories that explain the high volume of milk produced by goats with twins. One suggests a high secretion of placental lactogen during gestational periods of multiple births, which promotes lactogenesis in mammary gland (Goetsch et al., 2011). Meanwhile, the second explanation is attributed to an excess of sucking by twins, which produce an over stimuli on mammary gland inducing a higher milk secretion (Sanchez de la Rosa et al., 2006). Although both theories seem reasonable, the former seems more plausible because in absence of sucking, multiple births goats still produce more milk volume than single births goats (Crepaldi et al., 1999).

\section{Weight, body condition and size}

Goats breeders tend to select animals for dairy production according to their height and body condition, although not always a well corporal condition is synonymous of been the best milk producer. The energy efficiency in milk production is defined as the volume of milk produced per unit of body weight of the goat. That means that goats with a high basal metabolic rate will be more efficient in milk production, independently of their total size (Haenlein, 1996). In fact, the animal has to mobilize the corporal fat to recovery the weight lost during the last lactation period, so thinner goats could be more efficient in sustain a high quality milk production (Morand-Fehr, 2005). Therefore, is not recommended to categorize an animal as high or low milk produced just according to its corporal treats. Regression models have to be used to correlate the genotype with its corporal features and therefore, establish a good correspondence between its appearance and milk yield production (McLaren, 2016). Besides although the goat has a good corporal condition, if the goat is not well adapted to the new environment, their milk production could be restricted.

\section{Dry Period}

The pause between lactation periods is an important subject for goat farmers, especially to determine the right moment to begin a new lactation period without affecting the animal 
wellness. In general is recommended a dry period of 50 days to allow a rest of mammary gland, promoting the renewal of gland tissue. This dry period is essential in cow cattle but in goats seems not necessary. Apparently, in goat the involution of old cells and proliferation of new cells occurs at the same time after the delivery, reaching even a better milk yield in goats in absence or with shorter dry period. In MurcianoGranadinas goats the absence of a dry period reduce its milk yield $\left(1.73 \mathrm{~L} \cdot \mathrm{d}^{-1}\right)$, meanwhile in goats with dry period of 27 and 56 days the milk production was of 2.68 and $2.53 \mathrm{~L} \cdot \mathrm{d}^{-1}$. In this case a shorter dry period does not affect milk yield and increase the productivity of the herd starting earlier (Caja et al., 2006). Therefore, is important to establish an optimal dry period to each goat breed according to its own traits and its goat farming management conditions.

\section{Photoperiod}

The photoperiod is the main environmental factor that regulates the mating behavior of goats. During shorts light days its reproductive behavior is increased, meanwhile in long light days this response is repressed. That comportment is evolutionary set to reach the calving season and the start of lactation period on that year season where food is available and weather conditions are better for the kid growing. Nevertheless, in a productive goat farming, this natural response forbid their continuously milk production. Even although foods are in abundance and environmental factors are well controlled by the goat rancher. However, photoperiods can be controlled artificially. Although hormones treatments based on sexual hormones or circadian clock hormones to induce a favorable goat mating response in a year season not expected for natural goat. The artificial control of photoperiod is less invasive, cheaper and easily to perform, because consist in storage the herd early at the end of the day using darkness corrals to simulate a short period of light. The photoperiod treatments affect females and males and have good results, as well as, melatonin treatments using under-skin implants to release this circadian hormone directly to the blood. In addition, the "male effect" is totally complementary to the photoperiod managements if male are sexually active during the mating process.
In this way, is totally possible to produce goat milk during all the year, controlling the photoperiod of the herd and using the male effect to obtain a productive mating season, which means lately a productive dairy herd after the calving season (Gatica et al., 2012).

\section{Conclusion}

In conclusion and according to the literature we propose a general managements practice to produce goat milk during all the year and with an economic purpose in arid and desert zones (Figure 1). In summary the goat has to be efficiently in convert food in milk and that not necessary involve an animal with extraordinary corporal conditions or the preference of goat with twins births. The analysis of lactation period controlling milk quality and total volume of milk produced could suggest if the selected goat type for goat milk production is the most appropriate. Changes in goat diet or other management procedures, like stabbed or semi-stabbed regimens, also will be reflected on lactation curve, showing the efficiency of the respective changes. In addition, the analysis of each lactation period will shows the productive rate of each animal, determining the period to renewal the herd. The use of mature goat to start the lactation period is also recommended for arid and desert zones, with the aim of obtain a better milk production since the first lactation period. About the dry period, this factor has to be determined for each particular goat breed breeding on that respective farming condition.

Therefore, to perform a lactation period analysis in goat farming with economic interest, an initial collaboration with academic institution could improve the incorporation of these technical procedures in the management of local herd. The technical transference of the management knowledge about the control of goat extrinsic factor from academic laboratory to local goat ranchers is almost a social responsibility where government institution and political agricultural statements has also to be involved. Otherwise, the good intention without the respective support will would not allowed the necessary transformation of goat farming from auto-subsistence activity toward an economic and productive activity with social and economic impact on those families linked to goat farming in arid and desert zones. 


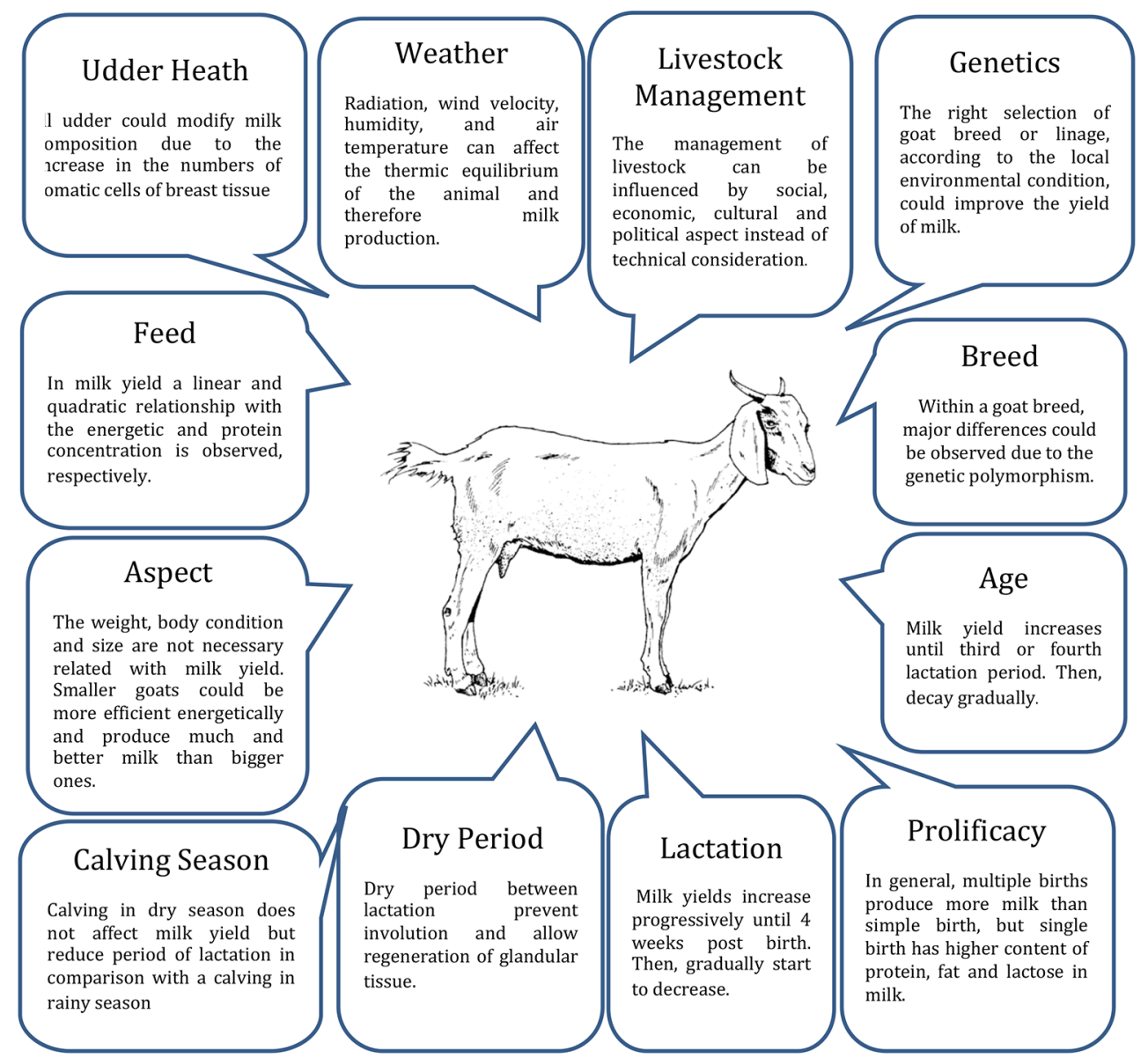

Figure 1. Factors that affect milk production and composition in goats.

\section{Literature Cited}

Bedoya-Mejía, O.; Posada, S.L.; Rosero-Noguera, R.

2012. Composición de la leche de cabra y factores nutricionales que afectan el contenido de sus componentes. En Posada, R. Desarrollo y Transversalidad serie Lasallista Investigación y Ciencia. Corporación Universitaria Lasallista. Antioquía, Colombia. 93-110.

Bidot, A.

2013. Producción de leche de cabra y duración de la lactancia de los genotipos nubia, saanen y toggenburg en condiciones de pastoreo restringido y suplemento con concentrado. Abanico Veterinario, 3: 30-35.

Caja, G.; Salama, A.A.K.; Such, X.

2006. Omitting the dry-off period negatively affects colostrum and milk yield in dairy goats. Journal of Dairy Science, 89: 4220-4228.

Carnicella, D.; Dario, M.; Ayres, M.C.C.; Laudadio, V.; Dario, C. 2008. The effect of diet, parity, year and number of kids on milk yield and milk composition in Maltese goat. Small Ruminant Research, 77: 71-74.

Cofré, $\mathrm{P}$.

2001. La cabra lechera en números. Producción de cabras lecheras. INIA, 66: 11-22.
Crepaldi, P.; Corti, M.; Cicogna, M.

1999. Factors affecting milk production and prolificacy of Alpine goats in Lombardy (Italy). Small Ruminant Research, 32: 83-88.

Delgado-Pertíñez, M.; Guzmán-Guerrero, J.L.; Caravaca, F.P.; Castel, J.M.; Ruiz, F.A.; González-Redondo, P.; Alcalde, M.J. 2009. Effect of artificial vs. natural rearing on milk yield, kid growth and cost in Payoya autochthonous dairy goats. Small Ruminant Research, 84: 108-115.

Espinosa, A.P.; Fundora, D.G.P.; Iglesias, D.G.; Villavicencio, J.L.E.; Pérez, R.O.; Trujillo, A.G.; Serrano, N.Á.

2016. Curvas de lactancia individuales en vacas Siboney de Cuba. Revista Mexicana de Ciencias Pecuarias, 7: 15-28.

Frau, S.; Togo, J.; Pece, N.; Paz, R.; Font, G.

2010. Estudio comparativo de la producción y composición de leche de cabra de dos razas diferentes en la provincia de Santiago del Estero. Revista de la Facultad de Agronomía, La Palta, 109: 9-15.

Fernández, G.; Mernies, B.

2016. Esquema de selección de la raza caprina Majorera: situación de partida, período 2012-2014. Arch. Zootec, 65: $457-460$ 
Gatica, M.C.; Celi, I.; Guzmán, J.L.; Zarazaga, L.A. 2012. Utilización de fotoperiodo e implantes de melatonina para el control de la reproducción en caprinos Mediterráneos. REDVET, 13: 1-15

Goetsch, A.L.; Zeng, S.S.; Gipson, T.A.

2011. Factors affecting goat milk production and quality. Small Ruminant Research, 101: 55-63.

Haenlein, G.F.

1996. Status and prospects of the dairy goat industry in the United States. Journal of Animal Science, 74: 1173-1181.

Leon, J.M.; Quiroz, J.; Pleguezuelos, J.; Martínez, E.;

Delgadoet, J.V.

2007. Curva de lactación para el número de lactancia en cabras Murciano-Granadinas. Archivos de Zootecnia, 56: 641-646.

Noguera, R.R.; Bedoya-Mejía, O.; Posada, S.L.

2011. Producción, composición de la leche y estatus metabólico de cabras lactantes suplementadas con ensilajes.

McLaren, A., Mucha, S., Mrode, R., Coffey, M., Conington, J. 2016. Genetic parameters of linear conformation type traits and their relationship with milk yield throughout lactation in mixed-breed dairy goats. Journal of Dairy Science, 99: 5516-5525.

Mioč, B.; Prpić, Z.; Vnučec, I.; Barać, Z.; Sušić, V.; Samaržija, D.; Pavić, V. 2008. Factors affecting goat milk yield and composition. Mljekarstvo, 58: 305-313.

Morand-Fehr, P.

2005. Recent developments in goat nutrition and application: A review. Small Ruminant Research, 60: 25-43.
Pérez, P.; Ferrando, G.; Alvear, C.; Berti, P.

1993. Curva de lactancia e influenza del número ordinal del parto en cabras criollas chilenas. Avances en Ciencias Veterinarias, 8: 38-43.

Peris, S.; Caja, G.; Such, X.; Casals, R.; Ferret, A.; Torre, C. 1997. Influence of kid rearing systems on milk composition and yield of Murciano-Granadina dairy goats. Journal of Dairy Science, 80: 3249-3255.

Sánchez de la Rosa, I.; Martínez Rojero, R.D.; Torres Hernández, G.; Becerril Pérez, C.M.; Mastache Lagunas, A.A.; Suárez Espinosa, J.; Rubio Rubio, M.

2006. Producción de leche y curvas de lactancia en tres razas de cabras en el trópico seco de México. Veterinaria México. 37: 493-502.

Salvador, A.; Martínez, G.

2007. Factores que afectan la producción y composición de la leche de cabra: Revisión bibliográfica. Rev. Fac. Cs. Vets, 48: 61-76.

Waheed, A., Khan, M.S.

2013. Lactation curve of Beetal goats in Pakistan. Archiv Tierzucht, 56: 892-898.

Zahradeen, D.; Butswat, I.S.R.; Mbap, S.T.

2009. A note on factors influencing milk yield of local goats under semi-intensive system in Sudan savannah ecological zone of Nigeria. Parity, 1: 442.

Zygoyiannis, D.

1994. A note on the effect of number and genotype of kids on milk yield and composition of indigenous Greek goats (Capra prisca). Animal Science, 58: 423-426. 


